\title{
Recent progress and perspectives on the mechanisms underlying Asbestos toxicity
}

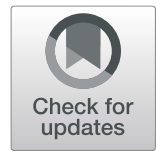

\author{
Akio Kuroda
}

\begin{abstract}
Most cases of mesothelioma are known to result from exposure to asbestos fibers in the environment or occupational ambient air. The following questions regarding asbestos toxicity remain partially unanswered: (i) why asbestos entering the alveoli during respiration exerts toxicity in the pleura; and (ii) how asbestos causes mesothelioma, even though human mesothelial cells are easily killed upon exposure to asbestos. As for the latter question, it is now thought that the frustrated phagocytosis of asbestos fibers by macrophages prolongs inflammatory responses and gives rise to a "mutagenic microenvironment" around mesothelial cells, resulting in their malignant transformation. Based on epidemiological and genetic studies, a carcinogenic model has been proposed in which BRCA1-associated protein 1 mutations are able to suppress cell death in mesothelial cells and increase genomic instability in the mutagenic microenvironment. This leads to additional mutations, such as CDKN2A [p16], NF2, TP53, LATS2, and SETD2, which are associated with mesothelioma carcinogenesis. Regarding the former question, the receptors involved in the intracellular uptake of asbestos and the mechanism of transfer of inhaled asbestos from the alveoli to the pleura are yet to be elucidated. Further studies using live-cell imaging techniques will be critical to fully understanding the mechanisms underlying asbestos toxicity.
\end{abstract}

Keywords: Asbestos, Toxicity, Mesothelioma, Carcinogenesis, Mutagenic microenvironment, BAP1, Live-cell imaging

\section{Background}

Asbestos is composed of bundles of fine silicate fibers (Fig. 1) and has been industrially used for its fire resistance, heat insulation, and strength. However, asbestos fibers are released into the air as asbestos-containing materials undergo mechanical damage or deterioration over time. The inhalation of asbestos fibers damages the lungs and can cause serious health problems, such as pleural mesothelioma and lung cancer [1-3]. The incidence of mesothelioma increased markedly after World War II when large amounts of asbestos were used [4]. The widespread use of asbestos continued until the early 1980s in the United States and Europe. By 1990, most developed countries reduced the use of asbestos.

Correspondence: akuroda@hiroshima-u.ac.jp

Unit of Biotechnology, Graduate School of Integrated Sciences for Life, Hiroshima University, 1-3-1 Kagamiyama, Higashi Hiroshima, Hiroshima 739-8530, Japan
However, it continues to be used in several countries, including India, China, and Russia. The World Health Organization (WHO) estimates that approximately 125 million people worldwide are exposed to asbestos in the workplace [5]. In countries where this is the case, the incidence and mortality due to mesothelioma are expected to increase.

While asbestos has been banned in most developed countries, large quantities of asbestos-containing materials remain in old buildings, and people are at risk of exposure to asbestos during demolition. In addition, natural minerals, such as talc, a raw material used in the manufacture of cosmetics, pharmaceuticals, and baby powder, may also contain asbestos. It has recently been highlighted that asbestos-contaminated talc may cause cancer [6,7]. According to the statistics reported by Global Burden of Diseases and Injury in 2016, the death toll due to mesothelioma in Japan and the United States

(c) The Author(s). 2021 Open Access This article is licensed under a Creative Commons Attribution 4.0 International License, which permits use, sharing, adaptation, distribution and reproduction in any medium or format, as long as you give appropriate credit to the original author(s) and the source, provide a link to the Creative Commons licence, and indicate if changes were made. The images or other third party material in this article are included in the article's Creative Commons licence, unless indicated otherwise in a credit line to the material. If material is not included in the article's Creative Commons licence and your intended use is not permitted by statutory regulation or exceeds the permitted use, you will need to obtain permission directly from the copyright holder. To view a copy of this licence, visit http://creativecommons.org/licenses/by/4.0/ The Creative Commons Public Domain Dedication waiver (http://creativecommons.org/publicdomain/zero/1.0/) applies to the data made available in this article, unless otherwise stated in a credit line to the data. 


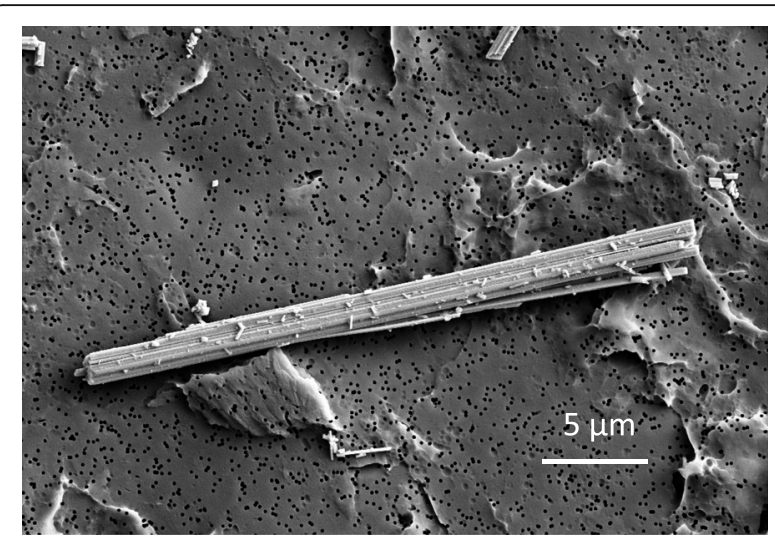

Fig. 1 Electron micrograph of asbestos. Amosite, obtained from the Japan Association for Working Environment Measurement (Tokyo, Japan), was observed by field emission scanning electron microscopy (Ultra Plus, Carl Zeiss)

remains high, at approximately 1500 and 3300, respectively [8]. Therefore, even years after the ban on the use of asbestos, the problem remains partly unresolved.

\section{Asbestos toxicity}

Asbestos is composed of six types of natural mineral fibers: chrysolite, amosite, crocidolite, actinolite, tremolite, and anthophyllite. In nature, there are 400 other types of mineral fibers, some of which are carcinogenic and associated with mesothelioma. Erionite, for example, is known to be a carcinogenic fiber and is associated with the mesothelioma epidemic in the village of Cappadocia, Turkey [9-11]. In contrast, palygorskite, which is present in desert dust, is reported to be noncarcinogenic [12]. The toxicity of a mineral fiber is related not only to the chemical composition of the mineral but also to its surface reactivity, crystallinity, and the presence of transition metals [13]. The size and shape of the fibers are also important since they affect whether the inhaled fibers penetrate the alveolar space through the airways [13]. The stability of the fibers in the lungs can greatly affect their toxicity since ones that reach the alveolar space may be degraded or removed by macrophages for detoxification.

The "mechanical interference mechanism" model was previously proposed, which predicted that phagocytosed asbestos fibers mechanically interact with the mitotic spindle and cause chromosomal changes, leading to carcinogenesis [14]. However, it was reported that human mesothelial cells were inevitably killed within 2-10 days of asbestos exposure, and no immortalized cell lines that could evolve into cancers were detected $[15,16]$. The mechanical interference mechanism is paradoxical since mesothelial cells are killed before they are transformed into cancer cells. The latency period of asbestos-induced mesothelioma is known to be $30-50$ years. Therefore, a long-term, chronic inflammatory asbestos-induced mechanism is considered the leading cause of carcinogenesis [17-20].

\section{Frustrated phagocytosis and continuous inflammation} Alveolar macrophages phagocytose particles, such as dust and microorganisms, and remove them from the surface of the alveoli. Alveolar macrophages also attempt to remove asbestos fibers via phagocytosis [21, 22]. It is reported that relatively short fibers appear to be completely encapsulated and removed by the phagosomes, so fibers less than $5 \mu \mathrm{m}$ in length are not retained in the lungs and do not cause chronic inflammation [23]. In contrast, longer fibers are imperfectly phagocytosed by macrophages, resulting in "frustrated phagocytosis" (Fig. 2), and can remain in the lungs for extended periods $[24,25]$. Long asbestos fibers are known to be associated with carcinogenesis [26]. Phagocytosed asbestos fibers activate the NOD-like receptor family pyrin domain containing 3 (NLRP3) inflammasome and trigger the production of the inflammatory interleukin-1ß (IL1ß) [27]. Therefore, long fibers retained in the lungs cause chronic inflammation, exerting a pleiotropic effect and resulting in malignant transformation. Since the toxicity of asbestos depends on the shape of the fibers, the WHO definition of asbestos is based on not only the mineralogy but also the fiber dimensions (length $\geq 5 \mu \mathrm{m}$, width $\leq 3 \mu \mathrm{m}$, and aspect ratio $\geq 3$ ).

The NLRP3 inflammasome responds to diverse numbers and structures of exogenous stimuli, including crystalline and particulate matter, extracellular adenosine

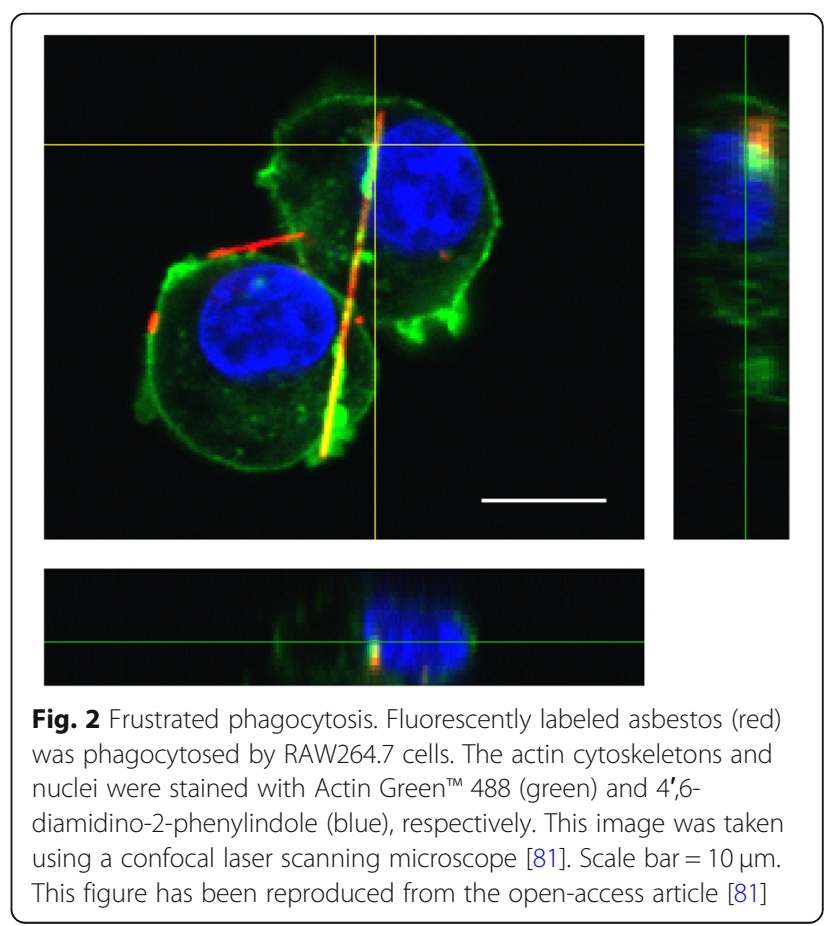


triphosphate, RNA-DNA hybrids, and various pathogens. Intraperitoneal injections of multi-walled carbon nanotubes (CNTs) have been reported to cause massive granulomatous inflammation in the diaphragms of wildtype mice [28]. Palomaki et al. found that both CNTs and asbestos induce the activation of the NLRP3 inflammasome in human macrophages [29]. Similarly, various crystals, such as silica, urate monohydrate crystals, hydroxyapatite, cholesterol, alum crystals, and nanomaterials such as $\mathrm{TiO}_{2}$ nanoparticles, have also been reported to induce NLRP3 inflammasome activation in macrophages [30-34].

The molecular mechanism underlying inflammasome activation has been extensively studied [35-38]. At least two signals are required for the activation of the NLRP3 inflammasome: the first signal (signal 1) induces the expression of NLRP3, along with pro-IL-1ß, via nuclear factor- $x \mathrm{~B}$; the second signal (signal 2) stimulates the assembly of multiple protein complexes, including NLRP3, apoptosis-associated speck-like protein containing a Cterminal caspase recruitment domain (ASC), and procaspase-1, resulting in the activation of caspase-1 protease. Subsequently, the active caspase- 1 processes pro-IL- $1 ß$ into mature IL-1ß, which is released extracellularly through the damaged macrophage membrane. Upon recognition of the crystal, macrophage surface receptors transmit signals 1 and/or 2. It is also proposed that the receptor-independent recognition of crystals may transmit signal 2 [39].

\section{Asbestos receptors}

Scavenger receptors, which are present only on macrophages and some endothelial cells, are involved in the recognition of a broad range of ligands. Class A scavenger receptors, such as class A scavenger receptor 1 and macrophage receptor with collagenous structure (MARCO), are known to bind to silica and titanium particles [40]. Murthy et al. reported that lower levels of fibrosis were seen in MARCO-deficient mice after exposure to chrysotile asbestos [41], indicating that MARCO may contribute, in part, to asbestos-induced pulmonary fibrosis. Recently, class B scavenger receptor member 1 (SR-B1) has been identified as a novel silica receptor [42]. SR-B1 could also act as an additional receptor for asbestos; however, this still needs to be confirmed experimentally. Meanwhile, an apparently unrelated receptor has been found to recognize particulate matter. Interestingly, T-cell membrane protein 4 , a phosphatidylserine receptor, has been reported to bind to CNTs and facilitate their cellular uptake [43].

\section{Carcinogenesis}

\section{(i) Mutagenic microenvironment}

Long asbestos fibers that reach the pleura are retained for extended periods of time [24, 25] and cause prolonged inflammation due to frustrated phagocytosis. The activated
NLRP3 inflammasome induces the secretion of IL-1ß [27]. Damaged and necrotic cells release inflammatory proteins, such as high mobility group box-1 protein (HMGB1), which induce the accumulation of macrophages and the activation of the NLRP3 inflammasome, resulting in amplification of the inflammatory response and secretion of tumor necrosis factor- $\alpha$ [19]. Inflammatory cells release reactive oxygen species (ROS) and reactive nitrogen species (RNS), which are capable of causing DNA damage [44, 45] (Fig. 3). Blake et al. found that asbestos fiber internalization generates a significant increase in intracellular ROS [46]. Xu et al. demonstrated that ROS mediate asbestos-induced DNA damage mutagenesis in humanhamster hybrid cells [17].

The histological diagnosis of asbestosis toxicity requires the presence of "an asbestos body," a core asbestos fiber coated with iron-containing materials. Therefore, asbestos toxicity is associated with iron [20, 47]. Intraperitoneal injection of ferric saccharate (glucaric acid-iron conjugate) can induce malignant mesothelioma [48, 49], suggesting that excess iron is involved in the carcinogenesis of mesothelioma. Toyokuni et al. proposed that macrophage necrosis occurs repeatedly along with lysosomal cell death [50], and ferroptosis [51] could establish an Fe (II)-rich mutagenic microenvironment [52], although they need to elucidate mutations induced under these conditions.

\section{(ii) suppression of cell death by BRCA1-associated protein 1 (BAP1) mutations}

It has been proven in three remote villages in Cappadocia, Turkey, that genetic predisposition is involved in the pathogenesis of mesothelioma. In 2001, Carbone et al. revealed that mesothelioma occurred primarily in only a subset of families in these villages, but not in others [11]. In 2011, the team conducted a study in two families in the United States who had not been exposed to asbestos; they found that the BAP1 mutation was associated with a high incidence of mesothelioma [53]. Among the somatic mutations occurring during tumor cell proliferation, $B A P 1$ mutations have been observed in approximately $60 \%$ of mesotheliomas [54-58]. BAP1 mutations are known to cause various types of cancers, including mesothelioma, and are referred to as " $B A P 1$ tumor predisposition syndrome" [59]. Genome analysis of mesothelioma has also revealed mutations in the CDKN2A [p16], NF2, TP53, LATS2, and SETD2 genes [57, 60]. In a mouse model, two pathways controlled by CDKN2 and TP53 are believed to be critical to the development of mesothelioma [61].

The BAP1 protein is a deubiquitylase that modulates the activity of multiple genes and proteins that control DNA replication, DNA repair, metabolism, and cell death [62, 63]. Bononi et al. reported that BAP1 


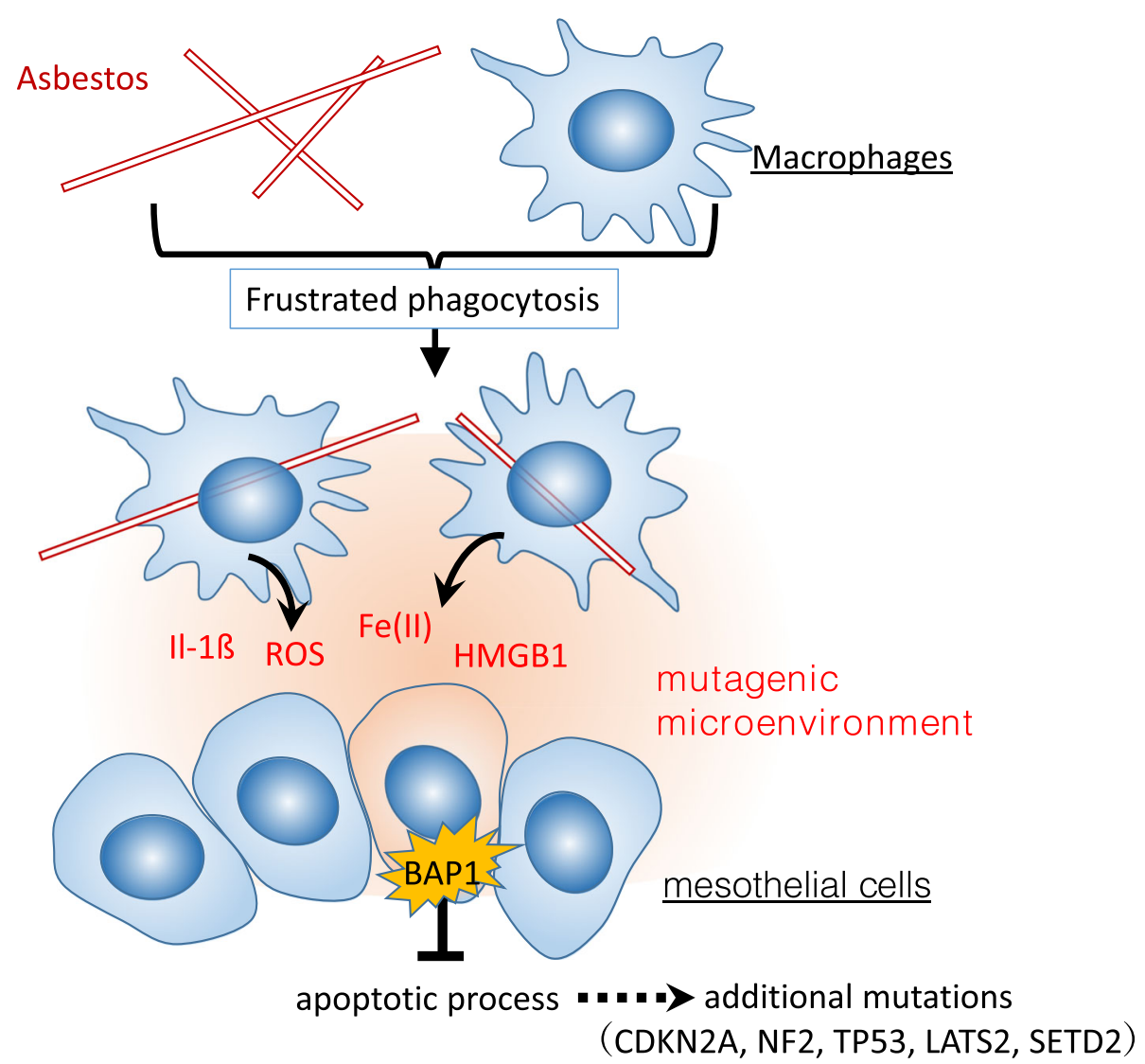

Fig. $3 \mathrm{~A}$ model of the carcinogenesis of mesothelioma in an asbestos-induced mutagenic microenvironment. Phagocytosed asbestos induces a mutagenic microenvironment rich in Fe (II), IL-1ß, ROS, and HMGB1 [16, 17, 19, 27, 46, 50-52]. The BAP1 mutation contributes to the suppression of mesothelial cell death and the accumulation of additional mutations associated with mesothelioma carcinogenesis [69]. Abbreviations: IL-1B: Interleukin-1B; ROS, reactive oxygen species; HMGB1, high mobility group box-1 protein; BAP1, BRCA1-associated protein 1

regulates both DNA repair and apoptosis following DNA damage caused by asbestos, ultraviolet light, radiation, or chemotherapy $[64,65]$. Zhang et al. reported that cells with reduced BAP1 activity are less prone to ferroptosis [66], indicating that BAP1 mutant cells can escape cell death [67]. Xue et al. noted that HMGB1 secreted during necrosis induces autophagy and suppresses apoptosis, leading to the accumulation of mutations associated with carcinogenesis [68].

It is known that no cancer cell lines arise from mesothelial cells in vitro upon exposure to asbestos [69]. Carbone et al. proposed a model that could explain the paradox of asbestos carcinogenicity [69]. First, the phagocytosed asbestos in macrophages may cause a mutagenic microenvironment rich in ROS and HMGB1, enhancing mutations in mesothelial cells. Then, BAP1mutated mesothelial cells may escape cell death and accumulate further DNA damage (CDKN2A, NF2, TP53, LATS2, SETD2), leading to carcinogenesis [67, 69] (Fig. 3 ). This model explains how mesothelial cells that have a short lifespan may form mesotheliomas after longterm inflammatory disorders [69]. In addition, Otsuki et al. have investigated the mechanisms of asbestos toxicity from the aspect of antitumor immunity [70, 71]. They found that $\mathrm{T}$ lymphocytes-dependent antitumor immunity was attenuated by the gradual exposure of asbestos to immune cells. This slow attenuation over a period of 30 to 50 years may contribute to malignant transformation in mesothelial cells.

\section{Dynamic analysis of asbestos by live-cell imaging}

It remains unclear why asbestos entering the alveoli during aspiration exerts toxicity in the pleura. Once asbestos fibers reach the pleura, they remain in the pleura due to their physical size. Therefore, the primary question that must be answered is how the asbestos fibers reach the pleura (Fig. 4) [31, 72-74]. Since alveolar macrophages have been implicated in the transfer of substances to the extracellular space or blood [75], macrophages may also be responsible for transferring asbestos fibers to the pleura.

The dynamic biological processes that occur during and after the internalization of asbestos fibers are not fully understood. This may partly be due to the 


\section{Pleura}

\section{fluid}

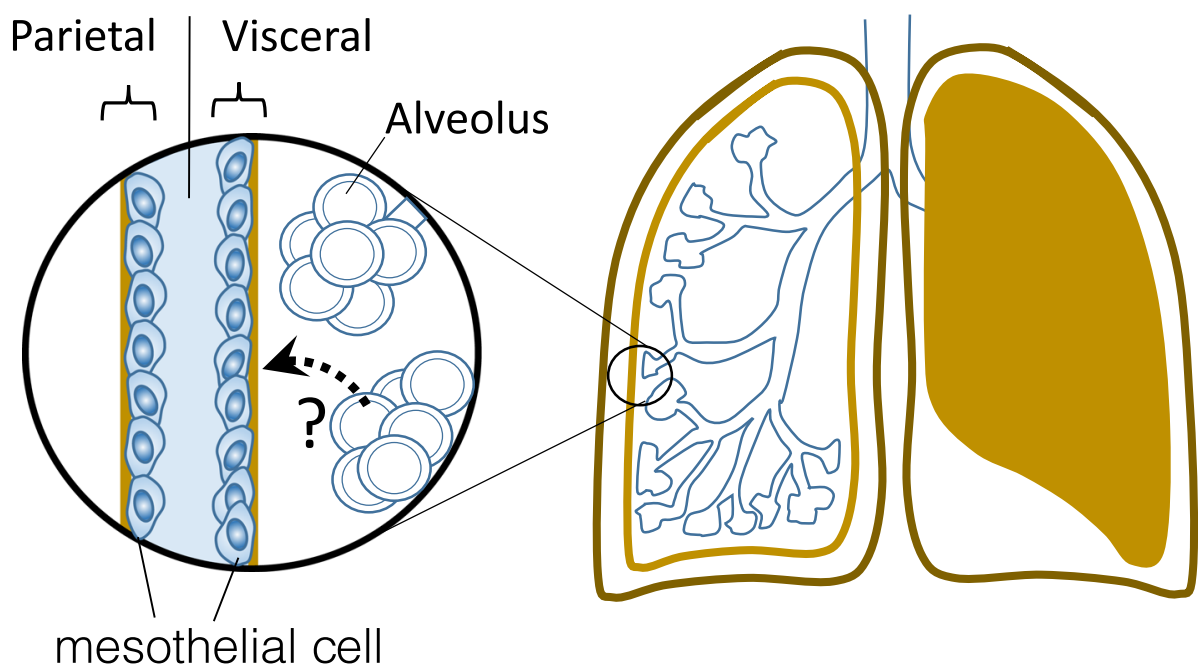

Fig. 4 Transport of asbestos fibers from the alveoli to the pleura

relative lack of developments in dynamic analytical techniques for the analysis of asbestos toxicity. Several studies have analyzed the intracellular internalization of asbestos fibers by transmission electron microscopy or a combination of atomic force microscopy and soft $\mathrm{X}$-ray microscopy $[46,76-78]$. These methods provide more detailed information than light microscopy but are not suitable for analyzing dynamic biological processes, such as those occurring during the phagocytosis of asbestos and the co-localization of biomolecules. A popular strategy for conducting dynamic analysis is live-cell imaging, using fluorescence microscopy. My collaborators and I have developed asbestos-binding protein-based fluorescent probes for environmental monitoring $[79,80]$ and live-cell imaging [81]. The finest fibers of chrysotile asbestos visualized by fluorescence microscopy are approximately $30-35 \mathrm{~nm}$ in diameter (estimated by scanning electron microscopy), which is similar to the dimensions of a single chrysotile fibril [82]. Fluorescently labeled asbestos and live-cell imaging are used in combination with confocal laser scanning microscopy to dynamically analyze the phagocytosis of asbestos (Fig. 2) and subsequent biological processes [81]. These techniques demonstrated that macrophages carrying internalized asbestos were motile (Video 1), indicating the involvement of macrophages in the transfer of asbestos to the pleura. In the future, such techniques may be used to elucidate the asbestos receptors involved in the pathogenesis and the mechanisms involved in asbestos transfer in vivo.

\section{Conclusions}

Paradoxical questions related to asbestos toxicity are explained by the frustrated phagocytosis of asbestos fibers by macrophages, which provide "a mutagenic microenvironment" around mesothelial cells and induce the BAP1 mutation. This mutation can contribute to the suppression of mesothelial cell death and the accumulation of additional mutations involved in mesothelioma carcinogenesis. The intracellular uptake of asbestos and the mechanisms involved in the transfer of inhaled asbestos must be fully understood in order to determine the mechanism underlying asbestos toxicity.

\section{Abbreviations}

BAP1: BRCA1-associated protein 1; WHO: World Health Organization; NLRP: Nucleotide-binding oligomerization domain, leucine-rich repeat, and pyrin domain-containing; IL-1ß: Interleukin-1ß; CNT: carbon nanotube; ASC: apoptosis-associated speck-like protein containing a C-terminal caspase recruitment domain; SR-B1: Class B scavenger receptors 1; HMGB1: High mobility group box-1 protein; ROS: Reactive oxygen species; MARCO: macrophage receptor with collagenous structure

\section{Supplementary Information}

The online version contains supplementary material available at https://doi. org/10.1186/s41021-021-00215-0.

Additional file 1: Video 1 Motility of macrophages that phagocytose asbestos (red). The detailed experimental conditions are described in reference [81].

\section{Acknowledgements}

The author thanks Mr. T. Nishimura for the electron microscope image of amosite and Dr. T. Ishida for editing Video 1. 


\section{Author's contributions}

The author wrote the manuscript and prepared the figures and illustrations.

\section{Funding}

This work was partly funded by the Environmental Restoration and Conservation Agency of Japan (grant number JPMEERF20195001) and by a Grant-in-Aid for Scientific Research from the Japan Society for the Promotion of Science (KAKENHI; grant number 19H04291).

\section{Availability of data and materials}

All data that were analyzed and reviewed are included in this article.

\section{Declarations}

Ethics approval and consent to participate

Not Applicable.

\section{Consent for publication}

Not Applicable.

\section{Competing interests}

The author has no conflicts of interest to declare.

Received: 17 July 2021 Accepted: 13 September 2021

Published online: 12 October 2021

\section{References}

1. Davis JM, Beckett ST, Bolton RE, Collings P, Middleton AP. Mass and number of fibres in the pathogenesis of asbestos-related lung disease in rats. $\mathrm{Br} J$ Cancer. 1978;37(5):673-88. https://doi.org/10.1038/bjc.1978.105.

2. Suzuki $Y$, Yuen SR, Ashley R. Short, thin asbestos fibers contribute to the development of human malignant mesothelioma: pathological evidence. Int J Hyg Environ Health. 2005;208(3):201-10. https://doi.org/10.1016/j.ijheh.2 005.01.015.

3. Kanarek MS. Mesothelioma from chrysotile asbestos: update. Ann Epidemiol. 2011;21(9):688-97. https://doi.org/10.1016/j.annepidem.2011.05.010.

4. Wagner JC, Sleggs CA, Marchand P. Diffuse pleural mesothelioma and asbestos exposure in the North Western Cape Province. Occup Environ Med. 1960;17(4):260-71. https://doi.org/10.1136/oem.17.4.260.

5. Park EK, Takahashi K, Jiang Y, Movahed M, Kameda T. Elimination of asbestos use and asbestos-related diseases: an unfinished story. Cancer Sci. 2012;103(10):1751-5. https://doi.org/10.1111/j.1349-7006.2012.02366.x.

6. Gordon RE, Fitzgerald S, Millette J. Asbestos in commercial cosmetic talcum powder as a cause of mesothelioma in women. Int J Occup Environ Health. 2014;20(4):318-32. https://doi.org/10.1179/2049396714Y.0000000081.

7. Moline J, Bevilacqua K, Alexandri M, Gordon RE. Mesothelioma associated with the use of cosmetic talc. J Occup Environ Med. 2020;62(1):11-7. https://doi.org/10.1097/JOM.0000000000001723.

8. Furuya S, Chimed-Ochir O, Takahashi K, David A, Takala J. Global Asbestos Disaster. Int J Environ Res Public Health. 2018;15(5):1000. https://doi.org/1 0.3390/ijerph15051000.

9. Bariş B, Demir AU, Shehu V, Karakoca Y, Kisacik G, Bariș YI. Environmental fibrous zeolite (erionite) exposure and malignant tumors other than mesothelioma. J Environ Pathol Toxicol Oncol. 1996;15:183-9.

10. Carbone M, Baris YI, Bertino P, Brass B, Comertpay S, Dogan AU, et al. Erionite exposure in North Dakota and Turkish villages with mesothelioma. Proc Natl Acad Sci U S A. 2011;108(33):13618-23. https://doi.org/10.1073/ pnas.1105887108.

11. Carbone M, Emri S, Dogan AU, Steele I, Tuncer M, Pass HI, et al. A mesothelioma epidemic in Cappadocia: scientific developments and unexpected social outcomes. Nat Rev Cancer. 2007;7(2):147-54. https://doi. org/10.1038/nrc2068.

12. Larson D, Powers A, Ambrosi JP, Tanji M, Napolitano A, Flores EG, et al. Investigating palygorskite's role in the development of mesothelioma in southern Nevada: insights into fiber-induced carcinogenicity. J Toxicol Environ Health, Part B. 2016;19(5-6):213-30. https://doi.org/10.1080/109374 04.2016.1195321.

13. Sanchez VC, Pietruska JR, Miselis NR, Hurt RH, Kane AB. Biopersistence and potential adverse health impacts of fibrous nanomaterials: what have we learned from asbestos? Wiley Interdiscip Rev: Nanomed Nanobiotechnol. 2009;1(5):511-29. https://doi.org/10.1002/wnan.41.
14. Olofsson K, Mark J. Specificity of asbestos-induced chromosomal aberrations in short-term cultured human mesothelial cells. Cancer Genet Cytogenet. 1989;41(1):33-9. https://doi.org/10.1016/0165-4608(89)90105-2.

15. Yang $H$, Bocchetta $M$, Kroczynska B, Elmishad AG, Chen $Y$, Liu Z, et al. TNF-a inhibits asbestos-induced cytotoxicity via a NF-kB-dependent pathway, a possible mechanism for asbestos-induced oncogenesis. Proc Natl Acad Sci U S A. 2006;103(27):10397-402. https://doi.org/10.1073/pnas.0604008103.

16. Wang Y, Faux SP, Hallden G, Kirn DH, Houghton CE, Lemoine NR, et al. Interleukin-1 $\beta$ and tumour necrosis factor-alpha promote the transformation of human immortalised mesothelial cells by erionite. Int J Oncol. 2004;25(1): $173-8$.

17. Xu A, Wu LJ, Santella RM, Hei TK. Role of oxyradicals in mutagenicity and DNA damage induced by crocidolite asbestos in mammalian cells. Cancer Res. 1999;59(23):5922-6.

18. Qi F, Okimoto G, Jube S, Napolitano A, Pass HI, Laczko R, et al. Continuous exposure to chrysotile asbestos can cause transformation of human mesothelial cells via HMGB1 and TNF-a signaling. Am J Pathol. 2013;183(5): 1654-66. https://doi.org/10.1016/j.ajpath.2013.07.029.

19. Carbone M, Yang H. Molecular pathways: targeting mechanisms of asbestos and erionite carcinogenesis in mesothelioma. Clin Cancer Res. 2012;18(3): 598-604. https://doi.org/10.1158/1078-0432.CCR-11-2259.

20. Toyokuni S. Iron addiction with ferroptosis-resistance in asbestos-induced mesothelial carcinogenesis: toward the era of mesothelioma prevention. Free Radic Biol Med. 2019;133:206-15. https://doi.org/10.1016/jfreera dbiomed.2018.10.401.

21. Lehnert BE. Defense mechanisms against inhaled particles and associated particle-cell interactions. In: Guthrie Jr GD, Mossman BT, editors. Health effects of mineral dusts. Berlin, Boston: De Gruyter; 2018. p. 427-70. https:// doi.org/10.1515/9781501509711-017.

22. Oberdörster G. Macrophage-associated responses to chrysotile. Ann Occup Hyg. 1994;38(4):601-15. https://doi.org/10.1093/annhyg/38.4.601.

23. Schinwald A, Murphy FA, Prina-Mello A, Poland CA, Byrne F, Movia D, et al. The threshold length for fiber-induced acute pleural inflammation: shedding light on the early events in asbestos-induced mesothelioma. Toxicol Sci. 2012;128(2):461-70. https://doi.org/10.1093/toxsci/kfs171.

24. Dörger M, Münzing S, Allmeling AM, Messmer K, Krombach F. Differential responses of rat alveolar and peritoneal macrophages to man-made vitreous fibers in vitro. Environ Res. 2001;85(3):207-14. https://doi.org/10.1 006/enrs.2001.4234

25. Schinwald A, Donaldson K. Use of back-scatter electron signals to visualise cell/ nanowires interactions in vitro and in vivo; frustrated phagocytosis of long fibres in macrophages and compartmentalisation in mesothelial cells in vivo. Part Fibre Toxicol. 2012;9(1):34. https://doi.org/10.1186/1743-8977-9-34.

26. Stanton MF, Layard M, Tegeris A, Miller E, May M, Morgan E, et al. Relation of particle dimension to carcinogenicity in amphibole asbestoses and other fibrous minerals. J Natl Cancer Inst. 1981;67(5):965-75.

27. Dostert C, Pétrilli V, Van Bruggen R, Steele C, Mossman BT, Tschopp J. Innate immune activation through Nalp3 inflammasome sensing of asbestos and silica. Science. 2008;320(5876):674-7. https://doi.org/10.1126/science.11 56995.

28. Poland CA, Duffin R, Kinloch I, Maynard A, Wallace WA, Seaton A, et al. Carbon nanotubes introduced into the abdominal cavity of mice show asbestos-like pathogenicity in a pilot study. Nat Nanotechnol. 2008;3(7):4238. https://doi.org/10.1038/nnano.2008.111.

29. Palomäki J, Välimäki E, Sund J, Vippola M, Clausen PA, Jensen KA, et al. Long, needle-like carbon nanotubes and asbestos activate the NLRP3 inflammasome through a similar mechanism. ACS Nano. 2011;5(9):6861-70. https://doi.org/10.1021/nn200595c.

30. Franklin BS, Mangan MS, Latz E. Crystal formation in inflammation. Annu Rev Immunol. 2016;34(1):173-202. https://doi.org/10.1146/annurevimmunol-041015-055539.

31. Donaldson K, Murphy FA, Duffin R, Poland CA. Asbestos, carbon nanotubes and the pleural mesothelium: a review of the hypothesis regarding the role of long fibre retention in the parietal pleura, inflammation and mesothelioma. Part Fibre Toxicol. 2010;7(1):5. https://doi.org/10.1186/17438977-7-5.

32. Mulay SR, Anders HJ. Crystallopathies. N Engl J Med. 2016;374(25):2465-76. https://doi.org/10.1056/NEJMra1601611.

33. Rock KL, Kataoka H, Lai JJ. Uric acid as a danger signal in gout and its comorbidities. Nat Rev Rheumatol. 2013:9(1):13-23. https://doi.org/10.1038/ nrrheum.2012.143. 
34. Tall AR, Yvan-Charvet $L$. Cholesterol, inflammation and innate immunity. Nat Rev Immunol. 2015;15(2):104-16. https://doi.org/10.1038/nri3793.

35. Broz P, Dixit VM. Inflammasomes: mechanism of assembly, regulation and signalling. Nat Rev Immunol. 2016;16(7):407-20. https://doi.org/10.1038/nri.2 016.58.

36. Gross O, Thomas CJ, Guarda G, Tschopp J. The inflammasome: an integrated view. Immunol Rev. 2011;243(1):136-51. https://doi.org/10.1111/ j.1600-065X.2011.01046.x

37. Latz E, Xiao TS, Stutz A. Activation and regulation of the inflammasomes. Nat Rev Immunol. 2013;13(6):397-411. https://doi.org/10.1038/nri3452.

38. Rathinam VA, Fitzgerald KA. Inflammasome complexes: emerging mechanisms and effector functions. Cell. 2016;165(4):792-800. https://doi. org/10.1016/j.cell.2016.03.046.

39. Nakayama M. Macrophage recognition of crystals and nanoparticles. Front Immunol. 2018;9:103. https://doi.org/10.3389/fimmu.2018.00103.

40. Thakur SA, Hamilton RF Jr, Holian A. Role of scavenger receptor a family in lung inflammation from exposure to environmental particles. J Immunotoxicol. 2008;5(2):151-7. https://doi.org/10.1080/15476910802 085863

41. Murthy S, Larson-Casey JL, Ryan AJ, He C, Kobzik L, Carter AB. Alternative activation of macrophages and pulmonary fibrosis are modulated by scavenger receptor, macrophage receptor with collagenous structure. FASEB J. 2015;29(8):3527-36. https://doi.org/10.1096/fj.15-271304.

42. Tsugita M, Morimoto N, Tashiro M, Kinoshita K, Nakayama M. SR-B1 is a silica receptor that mediates canonical Inflammasome activation. Cell Rep. 2017; 18(5):1298-311. https://doi.org/10.1016/j.celrep.2017.01.004.

43. Omori S, Tsugita M, Hoshikawa Y, Morita M, Ito F, Yamaguchi SI, et al. Tim4 recognizes carbon nanotubes and mediates phagocytosis leading to granuloma formation. Cell Rep. 2021;34(6):108734. https://doi.org/10.1016/j. celrep.2021.108734.

44. Kawanishi S, Ohnishi S, Ma N, Hiraku Y, Murata M. Crosstalk between DNA damage and inflammation in the multiple steps of carcinogenesis. Int J Mol Sci. 2017;18(8):1808. https://doi.org/10.3390/ijms18081808.

45. Valavanidis A, Vlachogianni T, Fiotakis K, Loridas S. Pulmonary oxidative stress, inflammation and cancer: respirable particulate matter, fibrous dusts and ozone as major causes of lung carcinogenesis through reactive oxygen species mechanisms. Int J Environ Res Public Health. 2013;10(9):3886-907. https://doi.org/10.3390/ijerph10093886.

46. Blake DJ, Bolin CM, Cox DP, Cardozo-Pelaez F, Pfau JC. Internalization of Libby amphibole asbestos and induction of oxidative stress in murine macrophages. Toxicol Sci. 2007;99(1):277-88. https://doi.org/10.1093/toxsci/ $\mathrm{kfm} 166$.

47. Nagai H, Okazaki Y, Chew SH, Misawa N, Yasui H, Toyokuni S. Deferasirox induces mesenchymal-epithelial transition in crocidolite-induced mesothelial carcinogenesis in rats. Cancer Prev Res. 2013;6(11):1222-30. https://doi.org/10.1158/1940-6207.CAPR-13-0244.

48. Okada S, Hamazaki S, Toyokuni S, Midorikawa O. Induction of mesothelioma by intraperitoneal injections of ferric saccharate in male Wistar rats. $\mathrm{Br} J$ Cancer. 1989;60(5):708-11. https://doi.org/10.1038/bjc.1989.344.

49. Hu Q, Akatsuka S, Yamashita Y, Ohara H, Nagai H, Okazaki Y, et al. Homozygous deletion of CDKN2A/2B is a hallmark of iron-induced highgrade rat mesothelioma. Lab Investig. 2010;90(3):360-73. https://doi.org/10.1 038/labinvest.2009.140.

50. Galluzzi L, Vitale I, Aaronson SA, Abrams JM, Adam D, Agostinis P, et al. Molecular mechanisms of cell death: recommendations of the nomenclature committee on cell death 2018. Cell Death Differ. 2018;25(3): 486-541. https://doi.org/10.1038/s41418-017-0012-4.

51. Stockwell BR, Angeli JPF, Bayir H, Bush Al, Conrad M, Dixon SJ, et al. Ferroptosis: a regulated cell death Nexus linking metabolism, redox biology, and disease. Cell. 2017;171(2):273-85. https://doi.org/10.1016/j.cell.2017.09.021.

52. Ito F, Yanatori I, Maeda Y, Nimura K, Ito S, Hirayama T, et al. Asbestos conceives Fe (II)-dependent mutagenic stromal milieu through ceaseless macrophage ferroptosis and beta-catenin induction in mesothelium. Redox Biol. 2020;36:101616. https://doi.org/10.1016/j.redox.2020.101616.

53. Testa JR, Cheung M, Pei J, Below JE, Tan Y, Sementino E, et al. Germline BAP1 mutations predispose to malignant mesothelioma. Nat Genet. 2011; 43(10):1022-5. https://doi.org/10.1038/ng.912.

54. Nasu M, Emi M, Pastorino S, Tanji M, Powers A, Luk H, et al. High incidence of somatic BAP1 alterations in sporadic malignant mesothelioma. J Thorac Oncol. 2015;10(4):565-76. https://doi.org/10.1 097/JTO.0000000000000471.
55. Guo G, Chmielecki J, Goparaju C, Heguy A, Dolgalev I, Carbone M, et al. Whole-exome sequencing reveals frequent genetic alterations in BAP1, NF2, CDKN2A, and CUL1 in malignant pleural mesothelioma. Cancer Res. 2015;75(2):264-9. https://doi.org/10.1158/0008-5472.CA $\mathrm{N}-14-1008$.

56. Lo lacono M, Monica V, Righi L, Grosso F, Libener R, Vatrano S, et al. Targeted next-generation sequencing of cancer genes in advanced stage malignant pleural mesothelioma: a retrospective study. J Thorac Oncol. 2015;10(3):492-9. https://doi.org/10.1097/JTO.0000000000000436.

57. Bueno R, Stawiski EW, Goldstein LD, Durinck S, De Rienzo A, Modrusan Z, et al. Comprehensive genomic analysis of malignant pleural mesothelioma identifies recurrent mutations, gene fusions and splicing alterations. Nat Genet. 2016;48(4):407-16. https://doi.org/10.1038/ng.3520.

58. Yoshikawa Y, Emi M, Nakano T, Gaudino G. Mesothelioma developing in carriers of inherited genetic mutations. Transl Lung Cancer Res. 2020; 9(Suppl 1):S67-76. https://doi.org/10.21037/tlcr.2019.11.15.

59. Pilarski R, Carlo M, Cebulla C, Abdel-Rahman M. BAP1 Tumor Predisposition Syndrome. In: Adam MP, Ardinger HH, Pagon RA, Wallace SE, Bean LJH, Mirzaa G, Amemiya A, editors. GeneReviews ${ }^{\circledast}$ [Internet]. Seattle (WA): University of Washington, Seattle; 2016. p. 1993-2021.

60. Hmeljak J, Sanchez-Vega F, Hoadley KA, Shih J, Stewart C, Heiman D, et al. Integrative molecular characterization of malignant pleural mesothelioma. Cancer Discov. 2018;8(12):1548-65. https://doi.org/10.1158/2159-8290.CD-18-0804.

61. Jean $D$, Jaurand MC. Mesotheliomas in genetically engineered mice unravel mechanism of mesothelial carcinogenesis. Int J Mol Sci. 2018;19(8):2191. https://doi.org/10.3390/ijms19082191.

62. Dey A, Seshasayee D, Noubade R, French DM, Liu J, Chaurushiya MS, et al. Loss of the tumor suppressor BAP1 causes myeloid transformation. Science. 2012;337(6101):1541-6. https://doi.org/10.1126/science.1221711.

63. Yu H, Pak H, Hammond-Martel I, Ghram M, Rodrigue A, Daou S, et al. Tumor suppressor and deubiquitinase BAP1 promotes DNA double-strand break repair. Proc Natl Acad Sci U S A. 2014;111(1):285-90. https://doi.org/10.1073/ pnas.1309085110.

64. Bononi A, Giorgi C, Patergnani S, Larson D, Verbruggen K, Tanji M, et al. BAP1 regulates IP3R3-mediated $\mathrm{ca}(2+)$ flux to mitochondria suppressing cell transformation. Nature. 2017:546(7659):549-53. https://doi.org/10.1038/na ture22798.

65. Bononi A, Yang H, Giorgi C, Patergnani S, Pellegrini L, Su M, et al. Germline BAP1 mutations induce a Warburg effect. Cell Death Differ. 2017;24(10): 1694-704. https://doi.org/10.1038/cdd.2017.95.

66. Zhang Y, Shi J, Liu X, Feng L, Gong Z, Koppula P, et al. BAP1 links metabolic regulation of ferroptosis to tumour suppression. Nat Cell Biol. 2018;20(10): 1181-92. https://doi.org/10.1038/s41556-018-0178-0.

67. Affar EB, Carbone M. BAP1 regulates different mechanisms of cell death. Cell Death Dis. 2018;9(12):1151. https://doi.org/10.1038/s41419-018-1206-5.

68. Xue J, Patergnani S, Giorgi C, Suarez J, Goto K, Bononi A, et al. Asbestos induces mesothelial cell transformation via HMGB1-driven autophagy. Proc Natl Acad Sci U S A. 2020;117(41):25543-52. https://doi.org/10.1073/pnas.2 007622117.

69. Carbone M, Adusumilli PS, Alexander HR Jr, Baas P, Bardelli F, Bononi A, et al. Mesothelioma: scientific clues for prevention, diagnosis, and therapy. CA Cancer J Clin. 2019;69(5):402-29. https://doi.org/10.3322/caa c.21572.

70. Otsuki T, Matsuzaki H, Lee S, Kumagai-Takei N, Yamamoto S, Hatayama T, et al. Environmental factors and human health: fibrous and particulate substance-induced immunological disorders and construction of a healthpromoting living environment. Environ Health Prev Med. 2016;21(2):71-81. https://doi.org/10.1007/s12199-015-0499-6.

71. Kumagai-Takei N, Lee S, Srinivas B, Shimizu Y, Sada N, Yoshitome K, et al. The Effects of Asbestos Fibers on Human T Cells. Int J Mol Sci. 2020;21(19).

72. Cugell DW, Kamp DW. Asbestos and the pleura: a review. Chest. 2004;125(3): 1103-17. https://doi.org/10.1378/chest.125.3.1103.

73. Suzuki Y, Kohyama N. Translocation of inhaled asbestos fibers from the lung to other tissues. Am J Ind Med. 1991;19(6):701-4. https://doi.org/10.1002/a jim.4700190603.

74. Dodson RF, O'Sullivan MF, Huang J, Holiday DB, Hammar SP. Asbestos in extrapulmonary sites: omentum and mesentery. Chest. 2000;117(2):486-93. https://doi.org/10.1378/chest.117.2.486.

75. Miserocchi G, Sancini G, Mantegazza F, Chiappino G. Translocation pathways for inhaled asbestos fibers. Environ Health. 2008;7(1):4. https://doi.org/10.11 86/1476-069X-7-4 
76. Jensen CG, Jensen LC, Rieder CL, Cole RW, Ault JG. Long crocidolite asbestos fibers cause polyploidy by sterically blocking cytokinesis. Carcinogenesis. 1996;17(9):2013-21. https://doi.org/10.1093/carcin/17.9.2013.

77. Wang NS, Jaurand MC, Magne L, Kheuang L, Pinchon MC, Bignon J. The interactions between asbestos fibers and metaphase chromosomes of rat pleural mesothelial cells in culture. A scanning and transmission electron microscopic study. Am J Pathol. 1987;126(2):343-9.

78. Gianoncelli A, Kourousias G, Cammisuli F, Cassese D, Rizzardi C, Radillo O, et al. Combined use of AFM and soft X-ray microscopy to reveal fibres' internalization in mesothelial cells. Analyst. 2017;142(11):1982-92. https://doi. org/10.1039/C6AN02661C.

79. Kuroda A, Alexandrov M, Nishimura T, Ishida T. Rapid on-site detection of airborne asbestos fibers and potentially hazardous nanomaterials using fluorescence microscopy-based biosensing. Biotechnol J. 2016;11(6):757-67. https://doi.org/10.1002/biot.201500438.

80. Kuroda A, Nishimura T, Ishida T, Hirota R, Nomura K. Detection of chrysotile asbestos by using a chrysotile-binding protein. Biotechnol Bioeng. 2008; 99(2):285-9. https://doi.org/10.1002/bit.21588.

81. Ishida T, Fujihara N, Nishimura T, Funabashi H, Hirota R, Ikeda T, et al. Livecell imaging of macrophage phagocytosis of asbestos fibers under fluorescence microscopy. Genes Environ. 2019;41(1):14. https://doi.org/10.11 86/s41021-019-0129-4.

82. Ishida T, Alexandrov M, Nishimura T, Minakawa K, Hirota R, Sekiguchi K, et al. Evaluation of sensitivity of fluorescence-based asbestos detection by correlative microscopy. J Fluoresc. 2012;22(1):357-63. https://doi.org/10.1 007/s10895-011-0967-3.

\section{Publisher's Note}

Springer Nature remains neutral with regard to jurisdictional claims in published maps and institutional affiliations.

Ready to submit your research? Choose BMC and benefit from:

- fast, convenient online submission

- thorough peer review by experienced researchers in your field

- rapid publication on acceptance

- support for research data, including large and complex data types

- gold Open Access which fosters wider collaboration and increased citations

- maximum visibility for your research: over $100 \mathrm{M}$ website views per year

At $\mathrm{BMC}$, research is always in progress.

Learn more biomedcentral.com/submissions 